\title{
Peningkatan kreativitas belajar biologi menggunakan model discovery learning pada siswa sekolah menengah atas
}

\author{
Sri Laspitorini \\ SMA Muhammadiyah 2 Yogyakarta. Jalan Kapas No.7, Kota Yogyakarta, Daerah Istimewa Yogyakarta 55166, Indonesia \\ rinilaspita@yahoo.com \\ * corresponding author
}

ARTICLE INFO

Keywords

Kreativitas

Biologi

Analisa deskriptif kualitatif

model Discovery Learning

\begin{abstract}
Tujuan penelitian ini adalah untuk meningkatkan kreativitas belajar Biologi dengan menggunakan model Discovery Learning pada siswa kelas XI MIA-1 SMA Muhammadiyah 2 Yogyakarta. Jenis penelitian ini adalah penelitian tindakan kelas (classroom action research). Penelitian dilaksanakan dalam dua siklus, siklus I dan siklus II. Masingmasing siklus terdiri dari dua pertemuan. Setiap pertemuan terdiri dari empat tahap yaitu perencanaan, pelaksanaan tindakan, observasi dan refleksi. Siswa yang dijadikan subjek penelitian ini adalah siswa kelas XI SMA Muhammadiyah 2 Yogyakarta tahun pelajaran 2016-2017 pada semester ganjil, dan peneliti menggunakan sampel kelas XI MIA-1 yang berjumlah 38 siswa, yang terdiri dari 20 siswa putri dan 18 siswa putra. Tekhnik pengumpulan data dilakukan dengan observasi, dokumentasi serta catatan lapangan. Analisis data dilakukan dengan metode analisis deskriptif kualitatif yaitu dengan membandingkan kreativitas siswa dalam pembelajaran biologi pada siklus I dan siklus II. Hasil penelitian menunjukkan adanya peningkatan kreativitas siswa dalam belajar biologi yang dapat dilihat dari: hasil penilaian kreativitas siklus I pertemuan pertama $51 \%$, pada pertemuan ke dua $63 \%$. Pada siklus II pertemuan pertama $75 \%$ dan pertemuan kedua menjadi $81,3 \%$. Berdasarkan hasil tersebut dapat disimpulkan bahwa penerapan model Discovery Learning dapat meningkatkan kreativitas siswa dalam pembelajaran Biologi.
\end{abstract}

This is an open access article under the CC-BY-SA license.

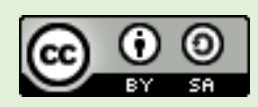

\section{PENDAHULUAN}

Menghadapi Kurikulum 2013 yang penerapannya banyak melibatkan siswa yaitu proses pembelajaran berpusat pada siswa (Prasetya, 2014; Setiana, 2016), guru diharapkan dan dituntut bisa sebagai motivator yang handal. Guru harus senantiasa meningkatkan mutu dalam proses pembelajaran yang bisa membuat siswa aktif, kreatif, inovatif dan senang. Jabaran UUD 1945 tentang pendidikan dituangkan dalam Undang-Undang Republik Indonesia Nomor 20 Tahun 2003 Tentang Sistem Pendidikan Nasional (2003) Pasal 3 menyebutkan, "Pendidikan nasional berfungsi mengembangkan kemampuan dan membentuk watak serta peradaban bangsa yang bermartabat dalam rangka mencerdaskan kehidupan bangsa, bertujuan untuk berkembangnya potensi peserta didik agar menjadi manusia yang beriman dan bertakwa kepada Tuhan Yang Maha Esa, berakhlak mulia, sehat, berilmu, cakap, kreatif, mandiri, dan menjadi warga negara yang demokratis serta bertanggung jawab." 
Dalam proses pembelajaran biologi guru diharapkan dapat mengembangkan kemampuan berpikir dan ketrampilan siswa, hal sesuai dengan pendapat Oemar hamalik yang menyatakan bahwa Pembelajaran biologi di sekolah menengah diharapkan dapat menjadi wahana bagi peserta didik untuk mempelajari diri sendiri dan alam sekitar serta proses pengembangan lebih lanjut dalam penerapannya di kehidupan sehari-hari. Penting sekali bagi setiap guru memahami sebaik-baiknya tentang proses belajar siswa, agar dapat memberikan bimbingan dan menyediakan lingkungan belajar yang tepat dan serasi bagi siswa (Hamalik, 2010).

Berdasarkan hasil pengamatan guru, proses pembelajaran mata pelajaran biologi di kelas XI MIA-1 SMA Muhammadiyah 2 Yogyakarta menunjukkan bahwa pemahaman dan kreativitas siswa dalam mengikuti pembelajaran masih belum optimal. Hal ini dikarenakan Ilmu biologi masih dianggap ilmu yang hanya mengutamakan hafalan istilah-istilah bahasa latin yang sulit dipahami siswa, materinya hanya dipelajari melalui teori-teori, gambar dan pengamatan mikroskopis saja. Jika system ini terus dilakukan maka kemampuan diri dan kreativitas siswa tidak akan tumbuh dan berkembang seperti yang diharapkan.

Ciri Kreativitas yang dimaksudkan adalah: (a) Mencetuskan banyak gagasan, jawaban, penyelesaian masalah atau pertanyaan, (b) Memberikan banyak cara atau saran untuk melakukan berbagai hal, (c) Menghasilkan gagasan jawaban atau pertanyaan-pertanyaan yang bervariasi, (d) Dapat melihat suatu masalah dari berbeda-beda sudut pandang, (e) Mencari banyak alternative, (f) Mampu menggunakan bermacam-macam pendekatan atau cara pemikiran. Orang yang kreatif adalah orang yang luwes dalam berpikir, (g) Mampu memperkaya dan mengembangkan gagasan atau produk, (h) Mampu menambahkan atau memperinci detail-detail dari suatu objek, gagasan atau situasi sehingga menjadi lebih menarik.

Pendekatan pembelajaran yang baik semaksimal mungkin melibatkan siswa secara aktif dan menjadikan pembelajaran itu lebih bermakna. Dengan proses pembelajaran yang inovatif dan kreatif akan diperoleh hasil belajar yang lebih baik. Untuk itu diperlukan adanya upaya yang dilakukan guru biologi untuk meningkatkan mutu pembelajaran yang akan meningkatkan prestasi dan kreativitas siswa. Banyak model yang dapat diterapkan untuk mengembangkan berpikir logis, kreatif, berpikir kritis dan menyenangkan, salah satu yang diterapkan penulis dalam hal ini yaitu dengan model pembelajaran Discovery learning.

Pembelajaran model Discovery learning adalah pembelajaran yang lebih menekankann ditemukannya konsep atau prinsip yang sebelumnya tidak diketahui, masalah yang dihadapkan adalah masalah yang direkayasa oleh guru. Materi yang akan disampaikan kepada siswa tidak dalam bentuk final tetapi siswa didorong untuk mengidentifikasi apa yang ingin diketahui dilanjutkan dengan mencari informasi kemudian mengorganisasi atau membentuk (konstruktif) apa yang mereka ketahui dan pahami dalam suatu bentuk akhir. Discovery learning ingin merubah kondisi belajar pasif menjadi aktif dan kreatif, siswa menemukan informasi sendiri.

Penulis memilih pendekatan pembelajaran Discovery learning ini karena mempunyai landasan filosofi nya adalah konstrukstivisme, yaitu filosofi belajar yang menekankan bahwa belajar tidak hanya sekedar menghafal. Siswa harus mengkostruksi pengetahuan di benak mereka sendiri. Konstruktivisme juga bersifat pragmatis yaitu sebuah filosogi belajar yang menekankan pada pengembangan minat dan pengalaman siswa. Melalui penerapan model pembelajaran Discovery learning ini diharapkan pemahaman, kreativitas pembelajaran biologi siswa kelas XI-MIA1 di SMA Muhammadiyah 2 Yogyakarta dapat meningkat. Untuk mengetahui manfaat model Discovery Learning maka peneliti memilih judul "Peningkatan Kreativitas Belajar Biologi Dengan Menggunakan Model Discovery Learning Pada Siswa Kelas XI MIA-1 SMA Muhammadiyah 2 Yogyakarta Tahun 2016".

\section{Definisi kreativitas}

Menurut Munandar (2014), kreativitas adalah kemampuan untuk membuat kombinasi baru, berdasarkan data, informasi atau unsur-unsur yang ada. Hasil yang diciptakan tidak selalu hal-hal yang baru, tetapi juga dapat berupa gabungan (kombinasi) dari hal-hal yang sudah ada sebelumnya. Selain itu, Baron (Munandar, 2014) menyatakan kreativitas adalah kemampuan untuk menghasilkan/menciptakan sesuatu yang baru. 


\section{Ciri-ciri kreativitas}

Ciri-ciri kreativitas adalah rasa atau hasrat ingin tahu, bersifat tebuka terhadap pengalaman baru, berkeinginan untuk menemukan dan meneliti, cenderung melakukan tugas yang berat dan sulit, bergairah, aktif dan mempunyai dedikasi dalam melakukan tugas, fleksibel, menanggapi pertanyaan dan kebiasaan untuk memberikan jawaban yang lebih banyak (Guilford, 1950). Seseorang dengan kreativitas dapat menganalisa semua permasalahan yang ada, serta mencari sintesisnya kemudian melakukan evaluasi.

Guilford mengemukakan ciri-ciri dari kreativitas antara lain (Guilford, 1950):

Kelancaran berpikir (fluency of thinking), yaitu kemampuan untuk menghasilkan banyak ide yang keluar dari pemikiran seseorang secara cepat. Adapun indikator kelancaran berpikir meliputi: (1) Mencetuskan banyak gagasan, jawaban, penyelesaian masalah atau pertanyaan, (2) Memberikan banyak cara atau saran untuk melakukan berbagai hal, (3) Selalu memberikan lebih dari satu jawaban.

Keluwesan berpikir (flexibility), yaitu kemampuan untuk menggunakan bermacam-macam pendekatan dalam mengatasi persoalan. Indikatornya meliputi: (1) Menghasilkan gagasan jawaban atau pertanyaan-pertanyaan yang bervariasi, (2) Dapat melihat suatu masalah dari berbeda-beda sudut pandang, (3) Mencari banyak alternatif, (4) Mampu menggunakan bermacam-macam pendekatan atau cara pemikiran. Orang yang kreatif adalah orang yang luwes dalam berpikir. Mereka dengan mudah dapat meninggalkan cara berpikir lama dan menggantikannya dengan cara berpikir yang baru.

Elaborasi (elaboration), yaitu kemampuan dalam mengembangkan gagasan dan menambahkan atau memperinci detail-detail dari suatu objek, gagasan atau situasi sehingga menjadi lebih menarik. Indikatornya yaitu: (1) Mampu memperkaya dan mengembangkan gagasan atau produk, (2) Mampu menambahkan atau memperinci detail-detail dari suatu objek, gagasan atau situasi sehingga menjadi lebih menarik.

Originalitas (originality), yaitu kemampuan untuk mencetuskan gagasan unik atau kemampuan untuk mencetuskan gagasan asli. Indikatornya yaitu: (1) mampu melahirkan ungkapan yang baru dan unik, (3) mampu memikirkan cara yang tidak lazim mengungkapkan diri, (3) mampu membuat kombinasi-kombinasi yang tidak lazim dari bagian-bagian atau unsur-unsur.

\section{Faktor-faktor yang mempengaruhi kreativitas}

Menurut Rogers (Munandar, 2014), faktor-faktor yang dapat mendorong terwujudnya kreativitas individu diantaranya:

\section{Dorongan dari dalam diri sendiri (motivasi intrinsik)}

Setiap individu memiliki kecenderungan atau dorongan dari dalam dirinya untuk berkreativitas, mewujudkan potensi, mengungkapkan dan mengaktifkan semua kapasitas yang dimilikinya. Dorongan ini merupakan motivasi primer untuk kreativitas ketika individu membentuk hubunganhubungan baru dengan lingkungannya dalam upaya menjadi dirinya sepenuhnya. Hal ini juga didukung oleh pendapat (Munandar, 2014) yang menyatakan individu harus memiliki motivasi intrinsik untuk melakukan sesuatu atas keinginan dari dirinya sendiri, selain didukung oleh perhatian, dorongan, dan pelatihan dari lingkungan.

\section{Dorongan dari lingkungan (motivasi ekstrinsik)}

Munandar (2014, p. 38) mengemukakan bahwa lingkungan yang dapat mempengaruhi kreativitas individu dapat berupa lingkungan keluarga, sekolah, dan masyarakat. Lingkungan keluarga merupakan kekuatan yang penting dan merupakan sumber pertama dan utama dalam pengembangan kreativitas individu. Pada lingkungan sekolah, pendidikan di setiap jenjangnya mulai dari pra sekolah hingga ke perguruan tinggi dapat berperan dalam menumbuhkan dan meningkatkan kreativitas individu. Pada lingkungan masyarakat, kebudayaan-kebudayaan yang berkembang dalam masyarakat juga turut mempengaruhi kreativitas individu. 


\section{Model Discovery Learning (DL)}

Pembelajaran model Discovery learning adalah pembelajaran yang lebih menekankann ditemukannya konsep atau prinsip yang sebelumnya tidak diketahui, masalah yang dihadapkan adalah masalah yang direkayasa oleh guru (Syarif, 2015). Materi yang akan disampaikan kepada siswa tidak dalam bentuk final tetapi siswa didorong untuk mengidentifikasi apa yang ingin diketahui dilanjutkan dengan mencari informasi kemudian mengorganisasi atau membentuk (konstruktif) apa yang mereka ketahui dan pahami dalam suatu bentuk akhir. Discovery learning ingin merubah kondisi belajar pasif menjadi aktif dan kreatif, siswa menemukan informasi sendiri. Proses pembelajarannya pada Tabel 1 .

Tabel 1. Materi pelatihan guru implementasi kurikulum 2013

\begin{tabular}{|c|c|c|c|c|}
\hline Sintak pembelajaran & \multicolumn{4}{|c|}{ Kegiatan pembelajaran } \\
\hline \multirow[t]{2}{*}{$\begin{array}{l}\text { Stimulation } \\
\text { (pemberian rangsangan) }\end{array}$} & \multicolumn{4}{|c|}{$\begin{array}{l}\text { Pada tahap ini peserta didik diberi motivasi untuk memusatkan perhatian pada topik materi } \\
\text { system gerak dengan cara: menayangkan gambar/ foto macam-macam tulang penyusun } \\
\text { rangka }\end{array}$} \\
\hline & $\begin{array}{l}\text { Tulang Rahang } \\
\text { Bawah (tak berbentuk) }\end{array}$ & $\begin{array}{l}\text { Tulang Lengan } \\
\text { Atas (pipa) }\end{array}$ & $\begin{array}{l}\text { Ruas Tulang } \\
\text { Belakang (pendek) }\end{array}$ & $\begin{array}{l}\text { Tulang Belikat } \\
\text { (pipih) }\end{array}$ \\
\hline $\begin{array}{l}\text { Problem statement } \\
\text { (identifikasi masalah) }\end{array}$ & \multicolumn{4}{|c|}{$\begin{array}{l}\text { Guru memberikan kesempatan pada siswa untuk mengidentifikasi sebanyak mungkin } \\
\text { pertanyaanyang berkaitan dengan gambar yang disajikan }\end{array}$} \\
\hline $\begin{array}{l}\text { Data collections } \\
\text { (pengumpulan data) }\end{array}$ & \multicolumn{4}{|c|}{$\begin{array}{l}\text { Siswa mengumpulkan informasi yang relevan untuk menjawab pertanyaan - pertanyaan } \\
\text { hasil identifikasi tersebut, dengan membaca literatur dari buku atau internet }\end{array}$} \\
\hline $\begin{array}{l}\text { Data prosescing } \\
\text { (pengolahan data) }\end{array}$ & \multicolumn{4}{|c|}{ Siswa berdiskusi dengan keompoknya untuk menjawab masalah/ pertanyaan dalam LK } \\
\hline Verrivication & \multicolumn{4}{|c|}{ Siswa berdiskusi untuk memverifikasi jawaban dengan pertanyaan dalam LK } \\
\hline Generalization/kesimpulan & \multicolumn{4}{|c|}{$\begin{array}{l}\text { Siswa menyimpulkan hasil diskusinya dan mempresentasikan di depan kelas } \\
\text { Guru membimbing dalam membuat kesimpulan kelas. }\end{array}$} \\
\hline
\end{tabular}

Siswa yang dijadikan subjek penelitian ini adalah siswa kelas XI SMA Muhammadiyah 2 Yogyakarta tahun pelajaran 2016-2017 pada semester ganjil, dan peneliti menggunakan sampel kelas XI MIA-1 yang berjumlah 38 siswa, yang terdiri dari 20 siswa putri dan 18 siswa putra. Penelitian ini akan dilaksanakan minimal dalam 2 siklus sesuai dengan tingkat keberhasilan yang dicapai. Dalam setiap siklusnya akan dilakukan satu tindakan, dalam tiap tindakannya diwujudkan dalam kegiatan belajar mengajar selama dua pertemuan yang lamanya 2 x 45 menit. Masing-masing terdiri dari empat tahap: perencanaan, tindakan, observasi dan refleksi.

Pengumpulan data dilakukan dengan beberapa teknik yaitu observasi, dan penugasan. Observasi dilakukan langsung oleh peneliti dan observer (kolaborator). Observasi dilakukan untuk mengetahui kreativitas siswa dalam pembelajaran biologi. Hal yang diamati sebagai indikator adalah minat siswa dalam belajar biologi, kelancaran berpikir, keluwesan berpikir, Elaborasi, keaktifan dalam mengajukan pertanyaan dan memunculkan ide-ide dalam diskusi selama proses pembelajaran biologi. Instrumen penelitian yang digunakan dalam penelitian ini ada 2, yaitu: (1) instrumen pengumpulan data, dan (2) instrumen analisis data. Instrumen pengumpulan data berupa lembar observasi, lembar dokumentasi. Instrumen analisis data berupa hasil observasi, hasil, dan catatan lapangan. Analisis data dilakukan dengan metode analisis deskriptif kualitatif yaitu analisis yang disajikan dalam bentuk kata-kata atau kualitatif

Uraian deskriptif ini berupaya memaparkan secara keseluruhan dari aktivitas pembelajaran, baik aktivitas guru maupun aktivitas siswa. Observasi yang dilakukan pada siswa meliputi kegiatan yang dilaksanakan siswa saat mengikuti pembelajaran, yaitu kemampuan siswa dalam berdiskusi dan presentasi serta kemampuan siswa dalam mengerjakan tahap-tahap penyelesaian yang disajikan, Dalam pengamatan ini digunakan lembar observasi. 
Tabel 2. Penilaian dalam observasi kreativitas siswa menggunakan pedoman penilaian

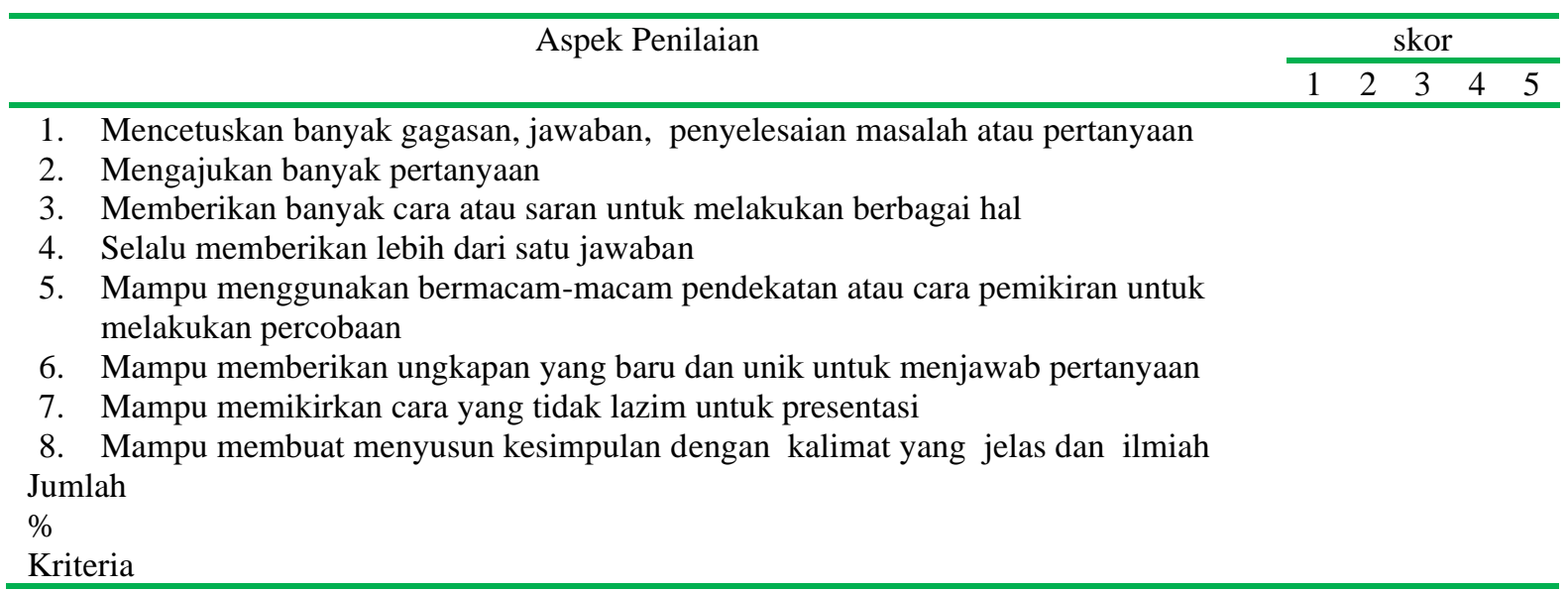

Berdasarkan uraian tersebut maka dapat dihitung kriteria kreativitas siswa dengan rumus:

Nilai kreativitas $=\frac{\text { Jumlah skor yang didapat }}{\text { Jumlah } \text { skor maksimal }} \times 100$

Tabel 3. Persentase Interval kreativitas siswa

\begin{tabular}{cc}
\hline Interval $(\%)$ & Kategori \\
\hline $91-100$ & Sangat baik \\
$81-90$ & Baik \\
$70-80$ & Cukup \\
kurang dari 70 & Kurang \\
\hline
\end{tabular}

\section{HASIL DAN PEMBAHASAN}

Penelitian ini dilakukan di kelas XI-MIA1 SMA Muhammadiyah 2 Yogyakarta tahun pelajaran 2015/2016 dengan jumlah siswa 38. Penelitian tindakan kelas dilakukan dalam 2 siklus yang masing-masing terdiri dari 2 pertemuan.

\section{Deskripsi Siklus I}

\section{Perencanaan}

Dalam tahap ini yang dilakukan dalam pertemuan 1 maupun pertemuan 2 yaitu: (1) Menyusun perangkat pembelajaran yaitu RPP, (2) Merinci alokasi waktu yang akan digunakan dalam tiap pembelajaran, setiap pertemuan 2 X 45 menit, (3) Membagi siswa menjadi 8 kelompok dengan model berhitung, (4) Menyusun instrumen penelitian yang terdiri dari lembar observasi kegiatan siswa dan lembar observasi kegiatan guru saat proses pembelajaran berlangsung.

Pelaksanaan tindakan

Pelaksanaan tindakan pada siklus I pertemuan ke-1 dilakukan hari Rabu, 28 September 2016 mulai pukul 12.30 sampai pukul 14.00 WIB. Kegiatan guru selama proses pembelajaran ini telah berlangsung sesuai prosedur rencana pelaksanaan pembelajaran. Kegiatan ini diawali dengan salam sebagai pembuka pelajaran. Guru memberikan apersespsi serta motivasi agar siswa mengingat kembali materi tentang jaringan hewan. Guru menyampaikan indikator dan tujuan pembelajaran yaitu siswa dapat menjelaskan ciri-ciri struktur dari jaringan hewan khususnya macam-macam jaringan otot yaitu otot polos, otot lurik dan otot jantung fungsi dan lokasinya. Pada kegiatan inti guru membentuk kelompok kerja yang beranggotakan 4 atau 5 orang dengan cara berhitung. Guru memberikan stimulus kepada siswa dengan memutar video pembelajaran tentang jaringan hewan. Siswa mengamati dengan seksama meskipun ada beberapa siswa yang kurang memperhatikan. Kemudian guru membagikan LKS, setelah guru membagikan LKS, guru menjelaskan prosedur kerja pengamatan mikroskopis tentang jaringan hewan khususnya jaringan otot. Semua anggota kelompok membaca LKS dan menyiapkan alat dan bahan praktikumnya. Salah atu siswa dalam kelompoknya 
mengamati struktur jaringan otot menggunakan mikroskop, preparat yang digunakan adalah preparat awetan yang disediakan guru. Setelah siswa menemukan objek yang tepat, kemudian objek pengamatan difoto dengan kamera HP tujuannya untuk mempermudah guru dalam menjelaskan bagianbagian dalam jaringan otot tersebut. Siswa mengamati objek, dan menngambar objek tersebut dalam LKS serta berdiskusi menjawab pertanyaan-pertanyaan dalam LKS. Setelah selesai berdiskusi, setiap kelompok menyampaikan hasil diskusinya di depan kelas dan kelompok lain menanggapi memberikan masukan atau mengajukan pertanyaan. Beberapa siswa memberikan komentar dan pertanyaan dengan antusias namun ada siswa yang kurang bersemangat, bahkan masih ada yang ramai membicarakan hal yang di luar materi pelajaran. Di akhir kegiatan, guru membantu siswa membuat kesimpulan secara klasikal dari kegiatan yang telah dilakukan. Guru mengingatkan siswa untuk mempelajari materi yang akan di bahas dalam pertemuan selanjutnya. Guru mengakhiri pelajaran dengan salam penutup.

Pelaksanaan tindakan pada siklus I pertemuan kedua dilaksanakan hari Jumat, 30 September 2016 pukul 07.00-08.30 WIB. Kegiatan guru selama proses pembelajaran ini yaitu: Kegiatan ini diawali dengan salam sebagai pembuka pelajaran. Guru memberikan apersespsi serta motivasi agar siswa mengingat kembali materi tentang jaringan hewan. Guru menyampaikan indikator dan tujuan pembelajaran yaitu siswa dapat menjelaskan ciri-ciri struktur dari jaringan hewan khususnya jaringan otot sesuai fungsinya untuk alat gerak aktif, Dalam kegiatan inti setelah guru membentuk kelompok kerja yang beranggotakan 4-5 orang kemudian memberikan apersepsi serta motivasi agar siswa mengingat kembali materi tentang jaringan otot. Guru memberikan stimulus kepada siswa dengan memutar video senam dan meminta siswa untuk mengikuti gerakan senam tersebut. Kemudian guru menjelaskan macam-macam gerak antagonis otot dengan media power point. Setelah membagikan LKS guru menjelaskan hal-hal yang harus dikerjakan sesuai LKS. Semua anggota kelompok membaca LKS dan berdiskusi. Selama siswa berdiskusi, guru berkeliling tiap kelompok dan melakukan tanya jawab pada masing-masing kelompok berhubungan dengan materi. Hal ini bertujuan untuk mengetahui kreativitas dan pemahaman siswa terhadap materi gerak antagonis otot yang disesuaikan dengan gerakan dalam kehidupan sehari-hari. Siswa menjelaskan macam-macam gerak antagonis dalam kegiatan sehari-hari maupun dalam gerakan olah raga misalnya volley, sepak bola, senam dan sebagainya. Setiap kelompok menyampaikan hasil diskusinya di depan kelas dan kelompok lain menanggapi/memberikan masukan. Beberapa siswa memberikan komentar dan pertanyaan dengan antusias, Di akhir kegiatan, guru bersama siswa membuat kesimpulan secara klasikal dari kegiatan yang telah dilakukan. Guru mengingatkan siswa untuk mempelajari materi yang akan di bahas dalam pertemuan selanjutnya. Guru mengakhiri pelajaran dengan salam penutup.

Hasil observasi

Berdasarkan observasi pembelajaran yang dilakukan kolaborator, data hasil observasi pembelajaran pada siklus I dan siklus II yaitu. Rerata kreatifitas siswa dalam pembelajaran siklus I adalah $51 \%$ dengan kategori kurang. Hal tersebut menunjukkan bahwa tingkat keberhasilan pembelajaran jaringan hewan pada siklus I belum maksimal karena belum mencapai kriteria seperti yang diharapkan yaitu $85 \%$. Hasil observasi menunjukkan bahwa rerata kreatifitas siswa dalam pembelajaran siklus I pertemuan kedua adalah $63 \%$ dengan kategori kurang. Hal tersebut menunjukkan bahwa tingkat keberhasilan pembelajaran jaringan hewan pada siklus I pertemuan kedua juga belum maksimal karena belum mencapai kriteria seperti yang diharapkan yaitu 85\%.

\section{Refleksi}

Kegiatan yang dilakukan pada tahap refleksi adalah mengkaji ulang hasil pelaksanaan siklus I pertemuan 1 untuk menentukan langkah perbaikan pada pertemuan ke 2. Kurang berhasilnya pembelajaran dengan metode discovery learning pada siklus I karena: (1) Masih banyak siswa yang belum secara aktif melakukan pengamatan mikroskop, (2) Ada beberapa siswa yang belum aktif dalam berdiskusi untuk membuat laporan praktikum cenderung bicara dengan temannya diluar materi pelajaran, (3) Beberapa siswa terlihat kurang bersemangat mengikuti pembelajaran

Maka langkah-langkah yang harus dilakukan: (1) Guru lebih memotivasi siswa yang masih aktif dalam proses pengamatan mikroskop, (2) Memberikan peringatan kepada siswa untuk lebih serius dalam mengikuti kegiatan diskusi, (3) Guru lebih memberikan bimbingan kepada siswa dalam mengembangkan kreatifitasnya. 


\section{Deskripsi Siklus II}

Perencanaan

Dalam tahap ini pertemuan ke ke satu dan ke dua ada beberapa hal yang dilakukan yaitu: (1) Menyusun perangkat pembelajaran yaitu RPP dengan materi gerak sendi, (2) Merinci alokasi waktu yang akan digunakan dalam tiap pembelajaran, setiap pertemuan 2 X 45 menit, (3) Membagi siswa menjadi beberapa kelompok, (4) Menyusun instrumen penelitian yang terdiri dari lembar observasi kegiatan siswa dan lembar observasi kegiatan guru saat proses pembelajaran berlangsung.

Pelaksanaan tindakan

Kegiatan ini diawali dengan salam sebagai pembuka pelajaran. Guru memberikan apersespsi serta motivasi agar siswa mengingat kembali materi pada pertemuan sebelumnya. Guru menyampaikan indikator dan tujuan pembelajaran. Pada kegiatan inti guru membentuk kelompok kerja yang beranggotakan 4-5 orang. Guru memberikan stimulus kepada siswa Setelah guru membagikan LKS, dan menjelaskan petunjuk kerja dalam LKS, semua anggota kelompok membaca LKS dan menyiapkan buku paket sebagai literatur. Setelah selesai berdiskusi, setiap kelompok mempresentasikan hasil diskusinya didepan kelas. Di akhir kegiatan, guru membantu siswa membuat kesimpulan secara klasikal dari kegiatan yang telah dilakukan. Di akhir pembelajaran, siswa dengan dibantu guru melakukan refleksi tentang kelebihan dan kekurangan pada saat pembelajaran dan menyimpulkan kegiatan dan materi yang dipelajari. Guru menutup pembelajaran dengan salam penutup. Guru mengingatkan siswa untuk mempelajari materi yang akan dibahas dalam pertemuan selanjutnya dan mengakhiri pelajaran dengan salam penutup.

Hasil observasi

Hasil observasi yang dilakukan kolaborator terhadap aktivitas guru pada siklus II pertemuan pertama adalah sebagai berikut. Dalam hasil observasi guru tersebut menunjukkan bahwa ada peningkatan kegiatan guru yang dilakukan dibandingkan dengan siklus I, meskipun masih ada siswa yang belum secara aktif melakukan diskusi untuk membuat laporan dan asik membicarakan hal lain di luar materi. Siswa dalam proses pembelajaran nampak semakin menyenangkan saat masing-masing kelompok presentasi, mereka berebut untuk mengajukan pertanyaan dan memberikan masukan. Hasil analisis menunjukkan bahwa rerata kreatifitas siswa dalam pembelajaran siklus II pertemuan ke 1 adalah $75 \%$ dengan kategori baik dan pada pertemuan ke 2 meningkat menjadi 81,3\% termasuk dalam kriteria baik. Hal ini menunjukkan adanya peningkatan yang signifikan pada kreativitas siswa dalam belajar biologi dengan model discovery learning.

Refleksi

Hasil refleksi pada siklus II adalah sebagai berikut: (1) Dalam hasil observasi kegiatan siswa siklus II pertemuan kedua tersebut menunjukkan bahawa aktifitas siswa dalam pembelajaran biologi semakin meningkat, (2) Siswa lebih tampak kreatifitasnya ditunjukkan dengan peningkatan ide-ide siswa dalam diskusi kelompok, (3) Sebagian besar siswa sudah menunjukkan keaktifan dan kreativitas-nya baik dalam berdiskusi maupun presentasi, (4) Kerja sama dan saling memotivasi antar teman sudah lebih meningkat dibandingkan pertemuan sebelumnya, (5) Keberhasilan ini juga didukung oleh guru yang menyiapkan RPP dan melaksanakan pembelajaran sesuai dengan yang direncanakan.

Tabel 4. Perbandingan hasil penilaian kreativitas siswa pada siklus I dan siklus II

\begin{tabular}{cccc}
\hline & Pertemuan 1 & Pertemuan 2 & Kriteria nilai \\
\hline Siklus I & $51 \%$ & $63 \%$ & kurang \\
Siklus II & $75 \%$ & $81,3 \%$ & Baik \\
\hline
\end{tabular}

\section{SIMPULAN}

Dari hasil penelitian ini dapat disimpulkan bahwa: (1) Penerapan model pembelajaran discovery learning dapat meningkatkan kreativitas belajar biologi siswa kelas XI MIA-1 SMA Muhammadiyah 2 Yogyakarta. Discovery learning ingin merubah kondisi belajar pasif menjadi aktif dan kreatif, siswa menemukan informasi sendiri, (2) Proses pembelajaran dalam model discovery learning meliputi: (a) Stimulation, (b) (pemberian rangsangan), (c) Problem statement (identifikasi masalah), 
(d) Data collections (pengumpulan data), (e) Data prosescing (pengolahan data), (f) Verrivication, (g) Generalization/kesimpulan, (3) Dalam proses pembelajarannya dilakukan dalam dua siklus yaitu siklus I terdiri dari dua pertemuan dan siklus II juga terdiri dari dua pertemuan. Setiap siklus berfungsi untuk mencapai tujuan peneliti yaitu untuk meningkatkan kreatifitas siswa dalm belajar biologi. Aspek pokok dalam penelitian tindakan memiliki empat tahapan dalam setiap siklus, yaitu penyusunan rencana, tindakan, observasi, dan refleksi (Madya, 2006, pp. 59-63). Dalam hal ini penelitian dilakukan untuk meningkatkan kreativitas pembelajaran biologi siswa kelas XI MIA-1 SMA Muhammadiyah 2 Yogyakarta, (4) Ada peningkatan yang signifikan pada kemampuan kreativitas belajar biologi siswa kelas XI MIA-1 SMA Muhammadiyah 2 Yogyakarta tahun pelajaran 2016 setelah diterapkan model pembelajaran Discovery learning. Pada Siklus I pertemuan pertama rerata kreativitas siswa sebesar $51 \%$, pada pertmuan kedua meningkat menjadi $63 \%$. Meskipun dengan katagori kurang tetapi ada peningkatan sekitar $12 \%$. Pada siklus II pertemuan pertama rerata kreativitas siswa 75\% dengan kriteria baik, pada pertemuan kedua meningkat menjadi 81,3\%. Berdasarkan peningkatan prosentase kreativitas siswa dalam belajar biologi maka penelitian dianggap berhasil dan pembelajaran dihentikan pada siklus II. Dengan demikian dapat disimpulkan bahwa penerapan model Discovery Learning dapat meningkatkan kreativitas siswa dalam pembelajaran biologi.

\section{REFERENSI}

Guilford, J. P. (1950). Creativity. American Psychologist, 5(9), 444.

Hamalik, O. (2010). Inovasi pendidikan: Perwujudannya dalam sistem pendidikan nasional. YP. Permindo.

Madya, S. (2006). Teori dan praktik penelitian tindakan. Alfabeta.

Munandar, U. (2014). Pengembangan kreativitas anak berbakat. Rineka Cipta.

Prasetya, S. P. (2014). Memfasiltasi pembelajaran berpusat pada siswa. Jurnal Geografi, 12(1), 112.

Undang-Undang Republik Indonesia nomor 20 tahun 2003 tentang sistem pendidikan nasional, Pub. L. No. 20, Undang-Undang Republik Indonesia 26 (2003).

Setiana, E. (2016). Penerapan model project based learning untuk meningkatkan kemampuan berpikir kreatif siswa SMA kelas XI [Universitas Negeri Semarang]. http://lib.unnes.ac.id/26700/

Syarif, M. (2015). Materi pelatihan guru Implementasi Kurikulum 2013 tahun 2015. Kementrian Pendidikan dan Kebudayaan. 